\title{
ROLLING AND ANNEALING EFFECTS ON MICROSTRUCTURE AND HARDNESS OF COMMERCIAL 405 STAINLESS STEEL
}

\author{
A. K. Jahja, N. Effendi and M. Dani \\ Center for Nuclear Industry Material Technology - BATAN \\ Puspiptek, Serpong, Tangerang 15314, Indonesia.
}

\begin{abstract}
ROLLING AND ANNEALING EFFECTS ON MICROSTRUCTURE AND HARDNESS OF COMMERCIAL 405 STAINLESS STEEL. The "cold-rolling" experiments for several values of true strain namely 5 percent, 10 percent, and 15 percent respectively have been carried out on commercial SS-405 steel samples at $350{ }^{\circ} \mathrm{C}$; the as-rolled samples were cut into several pieces in size of $10 \times 10 \times 5 \mathrm{~mm}^{3}$, and some pieces were annealed to $550{ }^{\circ} \mathrm{C}$ for 24 hours. All samples were then mounted and polished before etching in order to observe the grain boundaries. The microstructure observation on all samples was carried out by using optical microscope (MO), meanwhile X-ray diffraction technique was employed in order to support the identification of the existing phases and to verify changes with respect to crystal orientation; the hardness tests were carried out by using Vickers micro hardness tester. The microstructure observation supported by X-ray diffraction results shows that the phase grains of rolled sample tends to take the oblong-shape, accompanied by a preferred orientation predominantly inclined toward the (110) plane. The microhardness testing results show that there has been an increase in the hardness of the as-rolled samples; Mainly because of the nearly negligible thickness of the original sample (being only $5 \mathrm{~mm}$ in size), the 15 percent as-rolled samples exhibits only a slight reduction in hardness compared to the 10 percent as-rolled samples; The main cause of this effect is the movement of some dislocations infiltrating the surface resulting in the reduction of the inner-stress in the bulk of the samples. In the rolled-annealed samples there is a very significant reduction in hardness compared to the as-rolled samples. Here the main cause is the recrystallization process taking place during annealing, which tends to significantly reduce the dislocations.
\end{abstract}

Keywords: Commercial SS-405, Cold-rolling, Inner-Stress

\section{INTRODUCTION}

SS-405 is one of the most important types among several ferritic types of materials that can be used as high temperature operation materials [1]. The application of this material type for high temperature operation covers a wide-range, since due to it's alloying elements included as well as chrome, mangan, and silicon, the materials also have an excellent resistance to corrosion attack occurred during the high-temperature operation. For these reasons in the reactor power plant, SS-405 alloy can be used in various devices such as heat-exchangers, pressure tubes, and another hot environment devices or components. Therefore first and foremost the materials should be tested in a proper setting which closely resembles or simulates a high-temperature environment. As a pressure tube or heat-exchanger with high temperature environment, the material has to resist thermal stress, 
mechanical stress, and also corrosive environment. In materials undergoing a rolling process, which in turn is a plastic deformation process, some stress condition will be induced in the materials. This is understandable, because in a plastic deformation process the dislocation density would increase; dislocation in turn, will generate internal strains in the materials. And as a result, the stacking fault energy (SFE) will appear which from a thermodynamic point of view is considered to be an increase in Gibbs free-energy. Because of the high-energy state of the materials, the materials will undergo a recrystallitation process at annealing temperature of $550{ }^{\circ} \mathrm{C}$; in this process and especially in a stress condition no high activation energy is necessary, and recrystallatation process therefore should be accomplished at $550{ }^{\circ} \mathrm{C}$. To investigate whether the material is capable of resisting strains which arise when it is subjected to mechanical process during the operation, it must undergo a mechanical-treatment test; one of the mechanical tests carried out on the material is the rolling-test; its purpose is to investigate the mechanical properties of the material after the rolling-treatment, and sequentially to test the formability of the material. Tensile test requires a more sizable sample in a larger quantity with a definite or exact shape. But in this work, the samples used are of limited size, much smaller than the required size for tensile test. In this report the microstructure and micro hardness investigation on SS-405 samples were carried out to observe the occurrence of microstructural and hardness changes in the materials after being rolled with the true strains from 5 percent, 10 percent, up to 15 percent respectively, at a temperature of $350{ }^{\circ} \mathrm{C}$, named cold rolled; the reason of why 5-, 10-, and 15 percent deformations have been chosen is as follow: The untreated (original) sample is sufficiently thin (only $5 \mathrm{~mm}$ thick), and so a relatively "low" strain number of 5 percent is first chosen as experimental data, with the numbers of 10 - and 15 percent being the minimum natural sequential integral multiplication of 5 percent, so to speak. The latest manufacturing properties data of austenite steels shows that this type of steels has a tensile strength of $520 \mathrm{MPa}$ and an elongation of $30 \%$ at $650-800{ }^{\circ} \mathrm{C}$ annealing temperature [2]. The second objective of this work is to investigate the occurrence of microstructural and some mechanical properties changes if any, in some of the same samples after being annealed at $500{ }^{\circ} \mathrm{C}$ for 5 hours. The effect of heat treatment on polycrystalline alloys in hot-rolled and cold-drawn states, has been investigated. In particular, the microstructure, transformation temperatures as well as mechanical behavior in terms of both uniaxial monotonic testing and instrumented Vickers micro-indentation have been investigated. The results constitute a fundamental understanding of the effect of heat treatment on thermal/stress-induced martensite and resistance to plastic flow in this material [3]. In another work, microhardness measurements were carried out in a low carbon lamination steel after $6 \%$ of temper rolling, in order to evaluate local variations of work hardening as a function of crystallographic orientation [4]. 


\section{THEORETICAL REVIEW}

Components of an assembly are usually fabricated using a certain type of material or materials; The components' materials are carefully selected by matching their properties with the actual application requirements of the assembly. This actually means that knowledge of the kind of environment and condition in which the components are expected to perform is almost obligatory $[5 \mathrm{a}, \mathrm{b}]$. For instance, power reactor environment. Since SS-405 has been selected to be the subject matter in this work, it is also the preferrable material for heat-exchanger. Therefore it is compulsory for the material's, firstly, to be unaffected by high-temperature. Secondly, the material should also be resilient with respect to high pressure. This last condition is to prevent water in the power-reactor from running out because of untimely or a too rapid vaporization. The third condition or issue to be addressed here is the water condition itself; since the location of the exchanger is in the water medium which in itself is impure and hot, these facts would ultimately lead to a corrosive environment for the heat-exchanger. The fourth issue here is the presence of neutron beam radiation inside the power reactor, which puts the heat exchanger within an irradiation field of neutron-beams [6]. Based upon the brief discussions presented above it becomes very apparent that the material(s) in question merits a series of thorough investigations, at least the material(s)'s response with respect to the four parameters outlined above must be addressed and deserve clear and unambiguous answers. So it is clear that the objectives of this type of investigation should firstly be the material(s)'s response to temperature, secondly the material(s)'s response to mechanical stress [7], thirdly the material(s)'s response to a corrosive environment, and fourthly or lastly what is the material(s)' response to neutron irradiation beam. In this report, only one of the above aspects will be addressed namely the material(s)'s response to mechanical stress; to achieve this objective the material(s) formability will be investigated by subjecting the material(s) to a rolling process. In this case rolling is chosen as the experimental method since it could readily be used to modify the mechanical properties of materials through mechanical treatments. Besides, rolling is effectively used in the forming process of materials [8]. If an alloy is exposed to a rolling process, two important things will ultimately occur. First, its dislocation density would multiply; Secondly, the shape of phase morphology residing on the inside of the lateral face in the rolling direction also changes, brought about by plastic deformation occurring during cold-rolling of the materials. Multiplication of dislocation occurring in the course of deformation could be explained by a theory formulated by Frank Read, which could also be applied to tensile test. Multiple reproductions would affect dislocation in such a way that in the end, it would be very difficult for dislocation to move, and the material would harden or increases its hardness. If materials that are not very thick are subjected to continuous rolling until a higher reduction percentage is attained, some dislocation would penetrate the 
surface through the climb-mechanism. After a while, the hardness would undergo some saturation, and if the rolling process is carried on, then the so called etch pitch phenomenon would affect some section of the crystalline structure. Therefore, this work will involve rolling-process with a predertermined strain values, and this outlines in details below.

\section{EXPERIMENTAL METHODS}

The chemical composition of the SS-405 alloys in weight \% used in this study is shown in Table 1 [8].

Tabel 1. Chemical compositions of SS-405 sample in weight \% [8].

\begin{tabular}{|c|c|c|c|c|c|c|}
\hline $\mathrm{C}$ & $\mathrm{Cr}$ & $\mathrm{Mn}$ & $\mathrm{P}$ & $\mathrm{S}$ & $\mathrm{Si}$ & $\mathrm{Al}$ \\
\hline 0.08 & $11.5-14.5$ & 1.0 & 0.04 & 0.03 & 1.0 & $0.1-0.3$ \\
\hline
\end{tabular}

The sample was cut into several equal-sized pieces (with dimension of $200 \times 10 \times 5 \mathrm{~mm}^{3}$ ), and one of the samples is kept in an original condition named by original sample or first sample, used as a comparative sample; three pieces of the samples were cold rolled for several true strain namely $5 \%, 10 \%$, and $15 \%$ respectively at temperature of $350^{\circ} \mathrm{C}$, named by second sample; meanwhile another three pieces were annealed to $550^{\circ} \mathrm{C}$ after being cold rolled at $350^{\circ} \mathrm{C}$ as well as the second sample, named rolled-anneal samples or third sample. The sample preparation follows the common standard metallographic procedure [9].

The optical microscopy observation was carried out by optical microscopy (MO) apparatus; meanwhile the hardness testing was carried out by using Vickers micro hardness tester, by applying a load of $200 \mathrm{~g}$ each time. X-ray diffraction was carried out by using X-ray diffraction assembly. Optical micrographic (MO) observation were performed to observe any existing micro structural changes, if any, concurrently the micro hardness test was performed to observe any changes in the material's hardness after rolling and rolling-annealing treatment respectively. The micro hardness measurements are carried out at ten different consecutive equidistant positions starting from the edge and then moving toward the centre diagonally. The results are then averaged out to get the average magnitude of the micro hardness; this method should be approximately equal to a macro hardness measurement. X-ray diffraction was carried out to identify the existing phase in the samples and also preferred orientation of the phase grains after rolling, if any, and also their changes after rollingannealing treatment. 


\section{RESULTS AND DISCUSSION}

The following pictures form a series of the microstructure photographs from original SS-405 sample and the rolled one for several true strains namely $5 \%, 10 \%$, and $15 \%$ respectively at $350{ }^{\circ} \mathrm{C}$. The observation result by optical microscopy on the original SS-405 sample magnified by factor of 100 showing that the surface has a relatively smooth and homogenous appearance; this is shown in Figure 1.

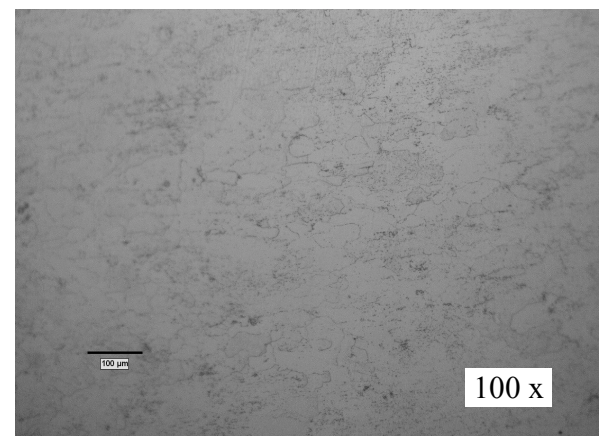

Figure 1. Observation result by optical micros copy on SS-405 original sample. No flat solid lines are visible here.

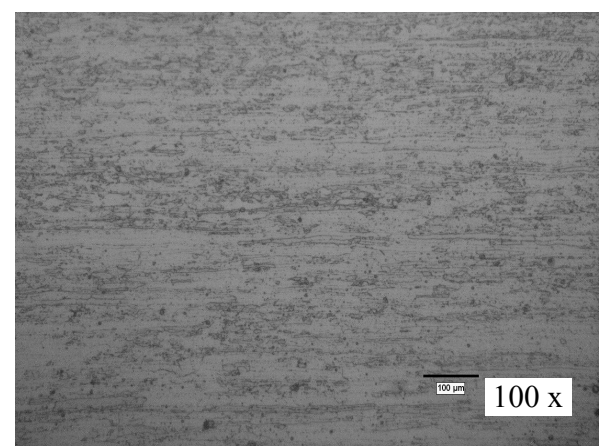

Figure 3. Micrograph of rolled SS-405 sample at $350{ }^{\circ} \mathrm{C}$ by $10 \%$ strain, taken from the sides of rolling direction. Compared to the 5\%-roll results in Figure 2, the $10 \%$ rolling product grains are much more visible here.

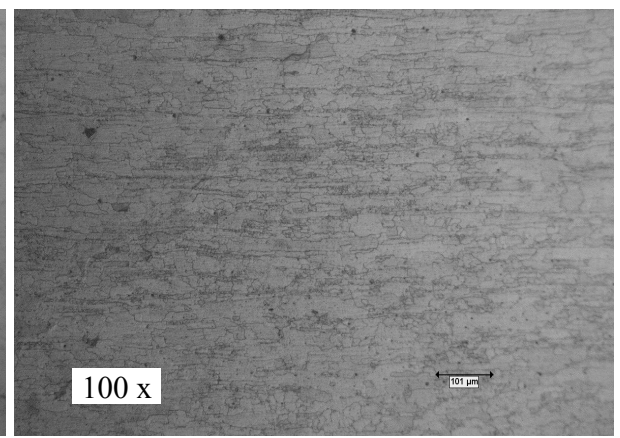

Figure 2. Observation result by optical microscopy on rolled sample of SS-405 at $350{ }^{\circ} \mathrm{C}$ by $5 \%$ strain, taken from the plane parallel to the rolling direction. Flat oblong grains are beginning to appear in the diagram, marked by elongated solid lines.

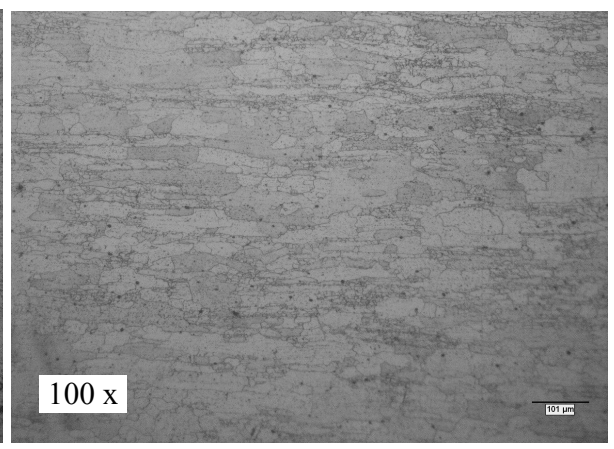

Figure 4. Micrograph of rolled SS-405 sample at $350{ }^{\circ} \mathrm{C}$ by $15 \%$ strain, taken from the sides of rolling direction. Here the flat grains tend to become thinner, resembling elongated straight lines. 
On the other hand, it first could be said that the shape of the grain phase in rolled materials take an oblong shape in line with the rolling direction. It is confirmed especially if we looked from the planes parallel to the rolling direction (i.e., longitudinal plane). So the observation result from the sides of rolling direction (cross section side) by optical microscope of the cold rolled sample (at $350{ }^{\circ} \mathrm{C}$ ) by $5 \%$ true strain magnified by a factor of 100 showing that the sample has a phase grains with the shape of elongated flat like, and the image was taken from the view to the edge oblique to the rolling direction; this is viewed in Figure 2. So do in Figure 3 and Figure 4, with the true strain of $10 \%$ and $15 \%$ respectively.
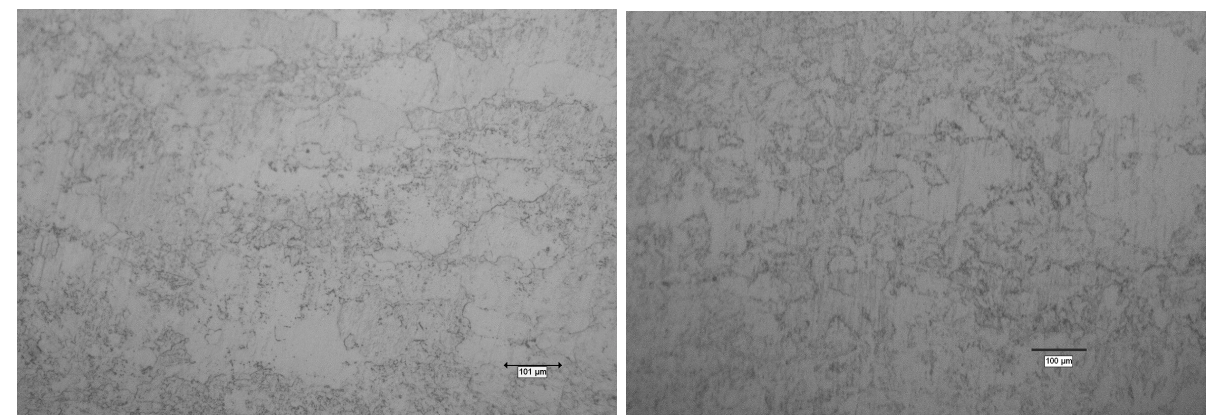

Figure 5. Micrograph of SS-405 rolled sample by $5 \%$ strain, taken from the top surface The form of the phase-grains does not appear to be flat and oblong

Figure 6. Micrograph of SS-405 rolled sample by $10 \%$ strain, taken from the top surface and the orientation of the phase-grain form does not appear to be flat and oblong

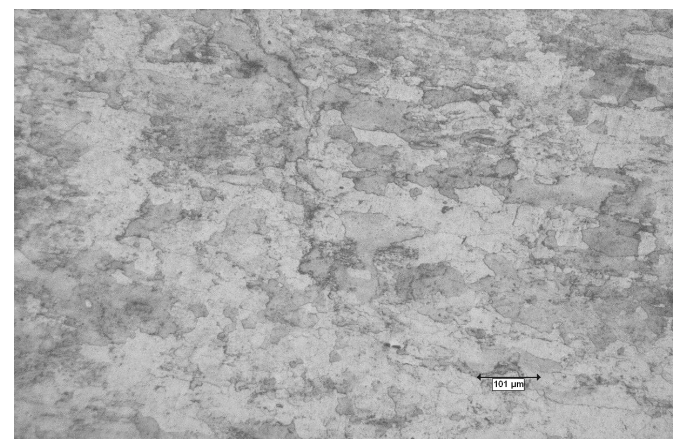

Figure 7. Micrograph of SS-405 rolled sample 15\% strain, taken from the top surface and here also the orientation of the phase-grain form does not appear to be flat and oblong. 
Figure 5 depicts microstructure of the same sample, as well as Figures 2 up to 4 , but the micrographs were taken from the top of the $5 \%$ true strain sample's surface; the same situation for Figures 6 and 7 for the $10 \%$ and $15 \%$ true strain samples respectively. In both of the last figures shown, the phase-grains' shape does not differ very much from the shape of the microstructure grains taken from the transversal cross section perpendicular the rolling direction (Figures 2 to 4 ). The phase grains at the top surface of the rolled sample have an elliptic shape randomly mixed with a semi elliptic shape but of non-homogenous sizes. Microstructure of the $5 \%$ true-strain rolled sample after annealing at $550{ }^{\circ} \mathrm{C}$ for 24 hours is shown in Figure 8; the micrograph was taken from top surface of the sample. Similar circumstances are also shown in Figure 9 and Figure 10 for the $10 \%$ and $15 \%$ true strain respectively.

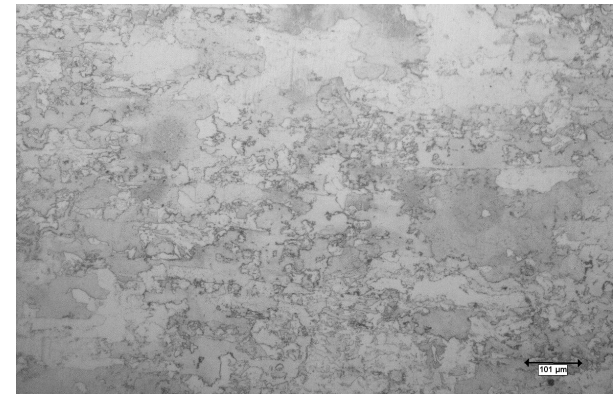

Figure 8. Micrograph of SS-405 rolled sample by $5 \%$ strain and then annealed to $550{ }^{\circ} \mathrm{C}$ for 24 hours, taken from the sample top surface.

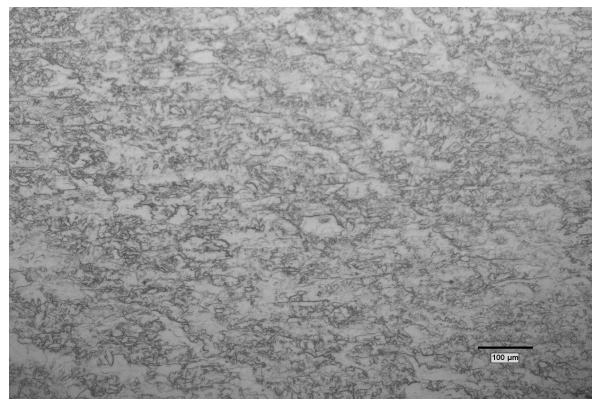

Figure 9. Micrograph of SS-405 rolled sample by $10 \%$ strain and then annealed to $550{ }^{\circ} \mathrm{C}$ for 24 hours, taken from the sample top Surface.

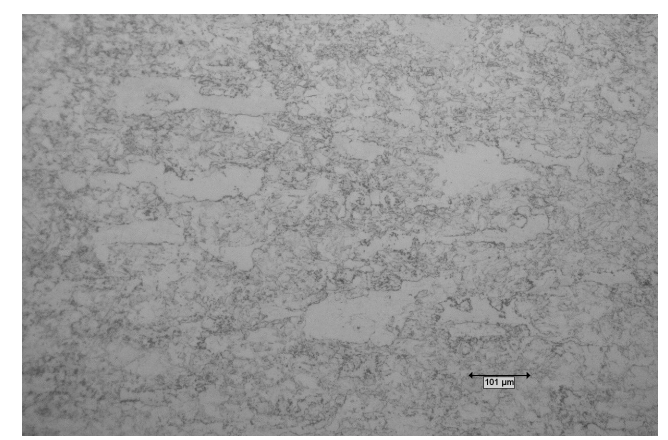

Figure 10. Micrograph of SS-405 rolled sample $15 \%$ strain and then annealed to $550{ }^{\circ} \mathrm{C}$ for 24 hours, taken from the top surface. 
Secondly, in rolled materials an increase in the dislocation density would ensure, because the mechanism of roll process is basically a plastic deformation process; therefore the hardness in rolled materials will increase and theoretically the material will have a lower ductility.

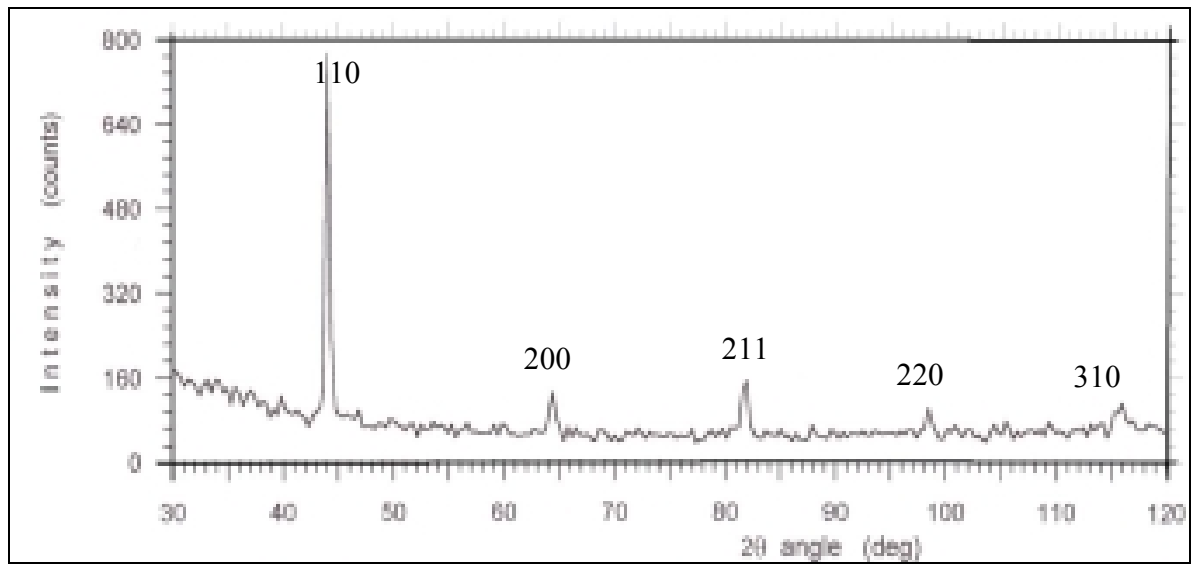

Figure 11. X-ray diffraction pattern of original commercial SS-405.

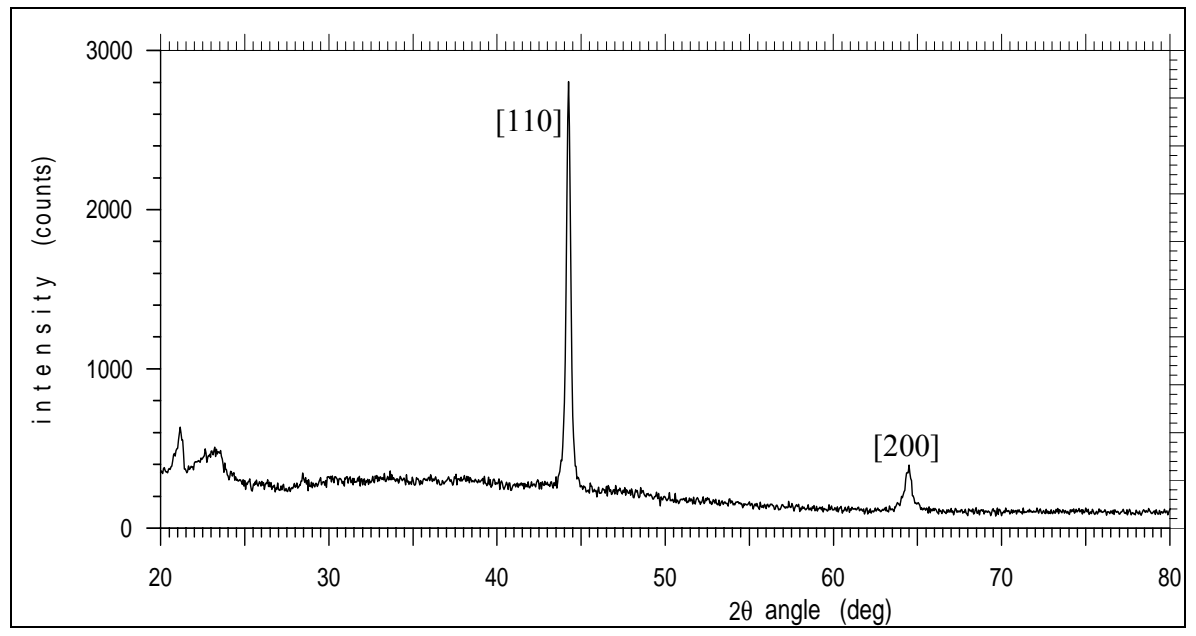

Figure 12. X-ray diffraction pattern of commercial SS-405 rolled with $5 \%$ strain. 


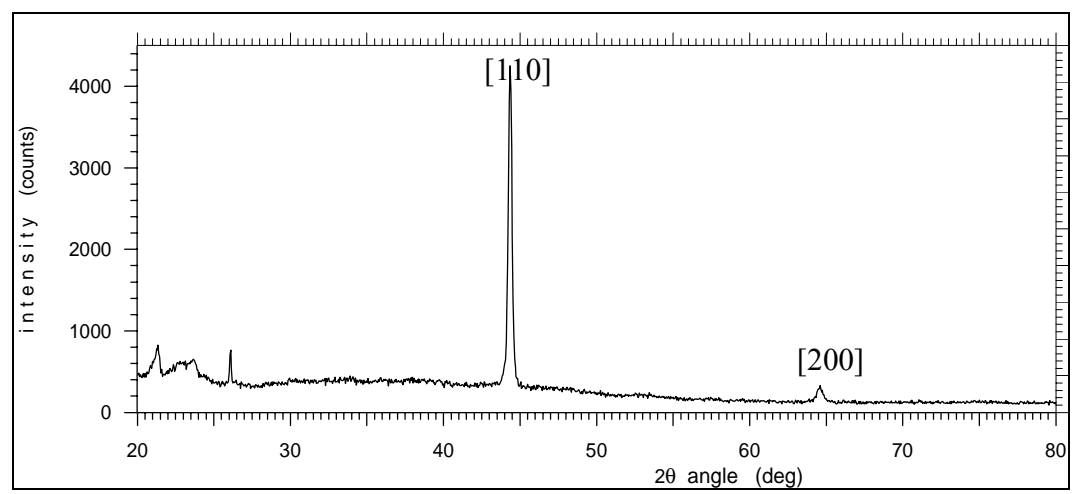

Figure 13. X-ray diffraction pattern of commercial SS-405 rolled with $10 \%$ strain.

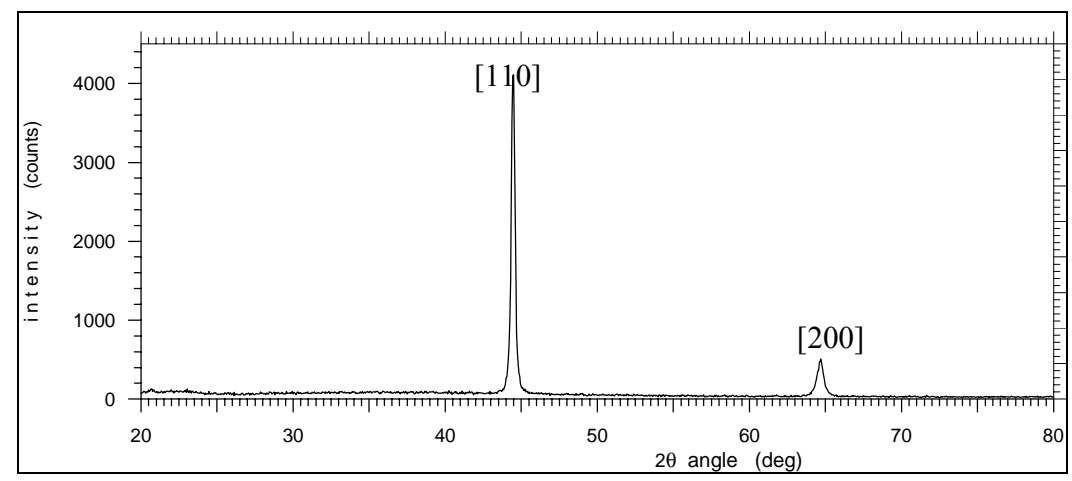

Figure 14. X-ray diffraction pattern of commercial SS-405 rolled with $15 \%$ strain.

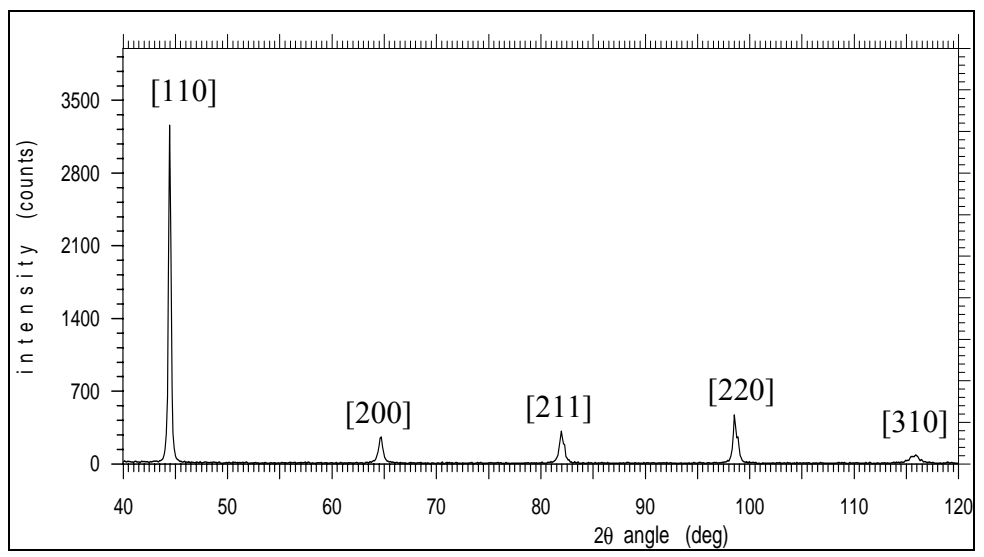

Figure 15. X-ray diffraction pattern of commercial SS-405 rolled with 5\% strain and then annealed at $550{ }^{\circ} \mathrm{C}$ for 24 hours. 


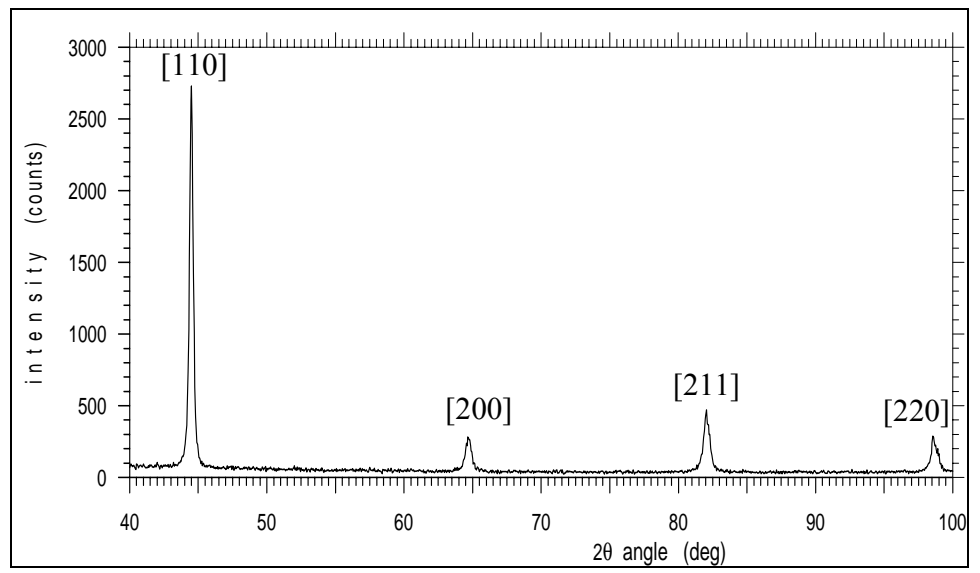

Figure 16. X-ray diffraction pattern of commercial SS-405 rolled with $10 \%$ strain and then annealed at $550{ }^{\circ} \mathrm{C}$ for 24 hours.

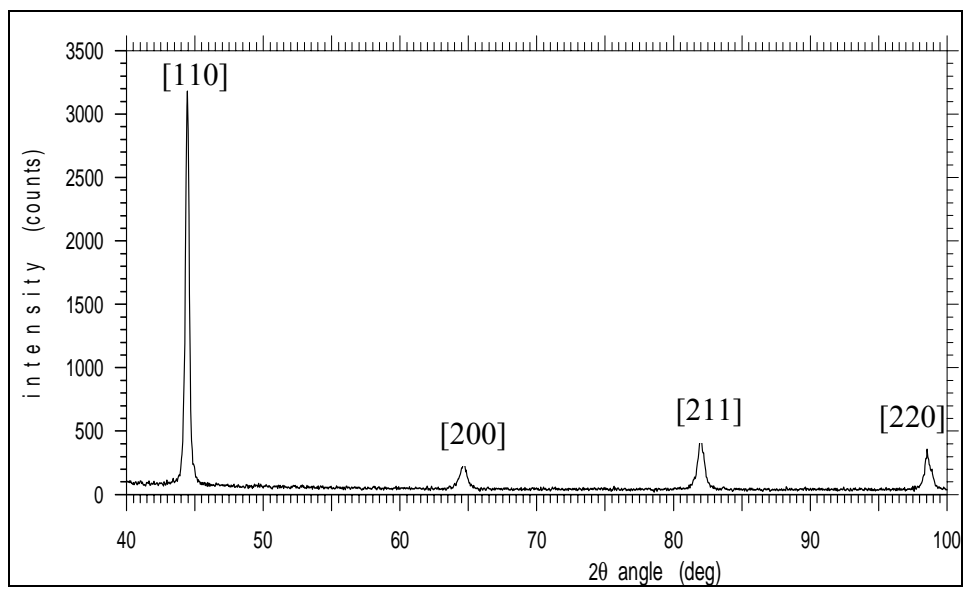

Figure 17. X-ray diffraction pattern of commercial SS-405 rolled with $15 \%$ strain and then annealed at $550{ }^{\circ} \mathrm{C}$ for 24 hours.

Figure 11 shows experimental diffraction results for untreated SS-405 samples. Diffraction pattern up to diffraction angle of $100^{\circ}$ shows the appearance of peaks in the [110], [200], [211] and [220] crystallographic directions corresponding to the bcc crystal system. The peaks represent abstract planes (Fourier) with definite [hkl] indices, in full measure with the integral combinations presented above. The maximum intensity is in the [110] direction, measuring fewer than 800 counts. Figure 12 shows experimental diffraction results of SS-405 samples after rolling with 5\% strain. The maximum intensity occurs in the [110] plane with a count of 2800 . This means that the rolled samples already exhibits 'preferred orientation' in 
the [110] direction. Figure 13, shows experimental diffraction results in SS-405 samples after 10\%-strain rolling. The pattern shows a maximum intensity of higher than 4000 counts in the [110] crystallographic direction. This experimental fact seems to supports the general view that 'preferred-orientation' would eventually take place in rolled samples. The higher the strain-values, the more opportunity for the 'preferred-orientation' to occur in a certain crystallographic direction, and in the case of SS-405 this happens to be the [110] direction. Figure 14, shows experimental diffraction results in SS405 direction after rolling with a $15 \%$ strain. This last diffraction pattern shows the appearance of maximum diffraction intensity also in the [110] direction with a higher than 4000 counts. From the diffraction data it could be observed that in rolled samples preferred orientation would normally take place along a particular, i.e. 'preferred' [hkl] direction, with the crystallite orientation being primarily redirected at the particular crystallographic plane. Figure 15 shows experimental diffraction results for SS-405 after rolling with 5\% strain followed by annealing for five hours. The maximum intensity in the [110] plane has diminished slightly compared with the identical unannealed just-rolled samples with $5 \%$ strain (see Figure 12). This is an indication that a slight decrease in the degree of preferred orientation has taken place in the annealed sample. Figure 16 depicts experimental diffraction results in SS-405 samples after rolling at $10 \%$-strain followed by annealing for five hours. In this diffraction pattern a sharp decrease in the [110]-plane maximum intensity was observed, in comparison with the maximum intensity of identical unannealed just-rolled samples with 10\% strain (see Figure 13). This finding would strongly supports the view that the degree of 'preferred orientation' tends to diminish in annealed samples. Figure 17 shows experimental diffraction results for SS-405 after rolling with $15 \%$ strain followed by annealing for five hours. Also here the maximum intensity in the [110] plane has diminished sharply compared with identical unannealed just-rolled samples with $15 \%$ strain (see Figure 12). These experimental diffraction data seems to supports the general view that in rolled and annealed samples, degradation in the 'preferred-orientation' degree would occur. This is readily understandable in terms of recovery in the samples affecting degradation in the degree of the samples 'preferred-orientation'. This is also compatible with the observed experimental facts, i.e. the decreasing diffraction intensity observed in these samples. Figure 18 shows the Vickers VHN hardness values for the original (untreated) samples and samples experiencing rolling (5-, 10-, and 15\%), and also for rolled samples with similar strain percentages but were annealed afterwards. The observed average VHN micro-hardness spread values with respect to the diagonal positions of the sample seems to point out that in the rolled samples, the micro-hardness values tend to increase, especially in comparison to the untreated samples. The reason behind this is that the rolling process is accompanied by plastic deformation process, which tends 
to increase the dislocation density in the samples, making it more difficult for the dislocations to move. The larger the strain, the bigger the dislocation density. A stagnation in the increase of this hardness value could be observed starting with the $15 \%$-strain samples; The main reason behind this is that some dislocations managed to penetrate through the surface and therefore decreases the tension inside the samples' bulk [10a,b]. One of the causes is the thinness of the original sample, which is only $5,0 \mathrm{~mm}$ thick; Therefore in an advanced rolling with increasing strain, the dislocation vector manages to penetrate the surface and cutting through the [110] plane. Optical microscopy investigation shows square-shaped spots in the samples' surface. In those samples with roll-anneal treatment, the average hardness values tend to decrease. This is the result of recovery mechanism prevailing in the samples during annealing [12b], as is already mentioned before. Recovery tends to decrease dislocation density, therefore decreasing samples' hardness. This condition is compatible with hardness data obtained above. Experimental results do indicate that the average micro-hardness values of the roll-anneal samples are lower compared to the values in roll-only samples [13].

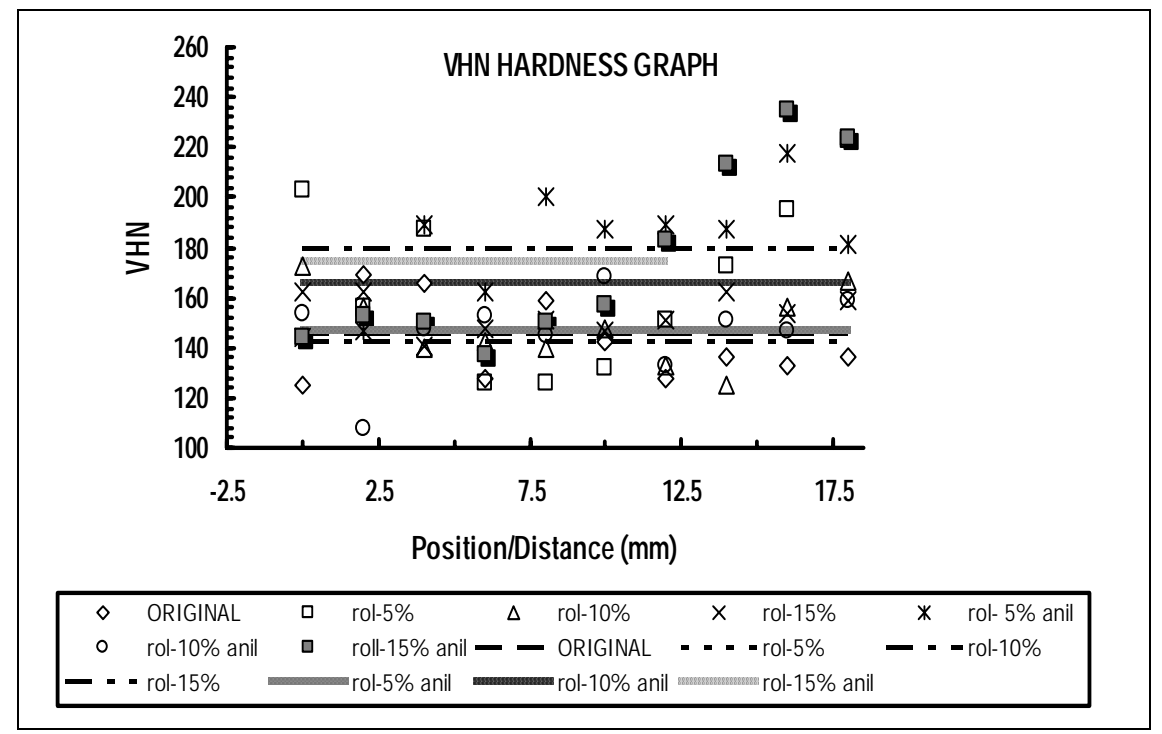

Figure 18. VHN Hardness measured at ten different equidistant location/position (indicated by markers) for commercial SS-405 rolled with 5\%,10\%,15\% strain (no-annealing and annealing treatment). The averaged values are indicated by solid lines. (VHN measured in the plane parallel to the rolling direction (longitudinal plane)). 


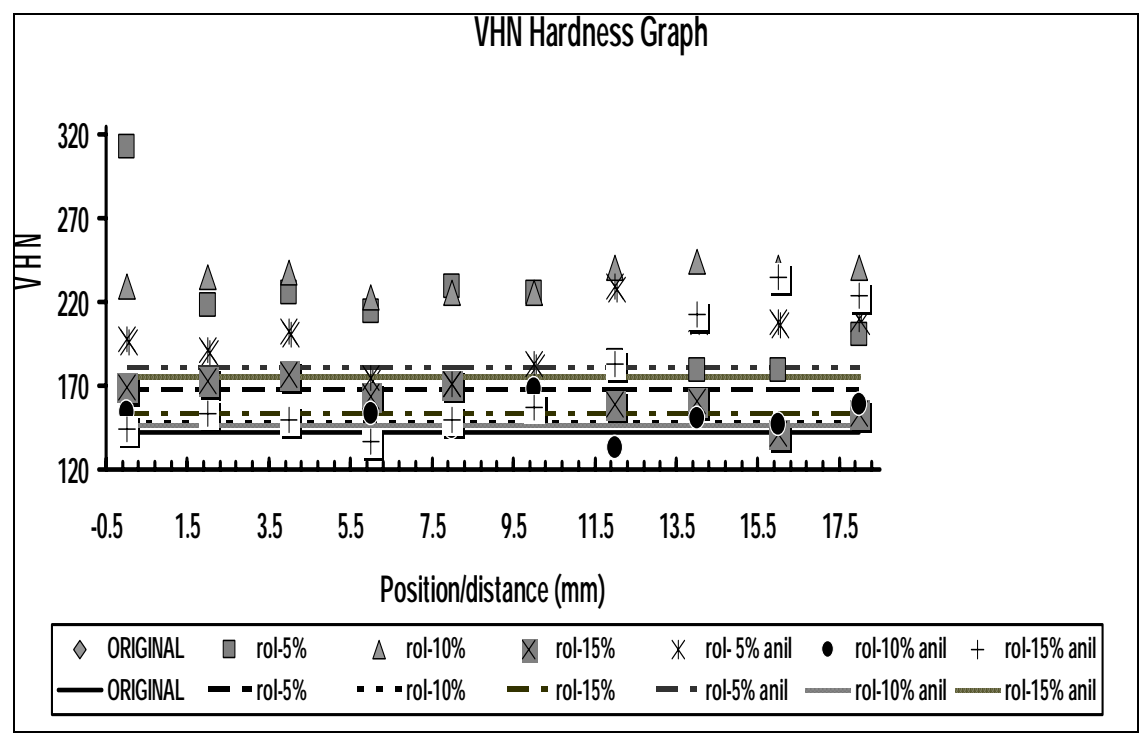

Figure 19. VHN Hardness measured at ten different equidistant location/position (indicated by markers) for commercial SS-405 rolled with $5 \%, 10 \%, 15 \%$ strain (no-annealing and annealing treatment). The averaged values are indicated by solid lines. (VHN measured in the plane perpendicular to the rolling direction (transversal plane)).

The average VHN values for the non-anneal and anneal cases are shown in Table 2 for the parallel and Table 3 for the perpendicular surface respectively. The intensity for the [110] preferred orientation peak is also shown in Table 2.

Table 2. Average VHN values and Intensity of the [110] preferred orientation peak (VHN measured in the plane parallel to the rolling direction (longitudinal plane)).

A: annealed at $550{ }^{\circ} \mathrm{C}$ for 24 hours NA: No anneal

\begin{tabular}{|c|c|c|c|c|c|c|c|}
\hline & original & \multicolumn{2}{|c|}{ Roll 5\% } & \multicolumn{2}{c|}{ Roll 10\% } & \multicolumn{2}{c|}{ Roll 15\% } \\
\cline { 3 - 8 } & NA & A & NA & A & NA & A \\
\hline $\begin{array}{c}\overline{\mathrm{VHN}} \\
\left(\mathrm{kg} / \mathrm{mm}^{2}\right)\end{array}$ & 175 & 167 & 148 & 180 & 147 & 142 & 175 \\
\hline $\begin{array}{c}\text { Intensity } \\
{[110]} \\
\text { peak } \\
\text { (a.u.) }\end{array}$ & 588 & 2900 & 3300 & 4300 & 2700 & 4300 & 3200 \\
\hline
\end{tabular}


Table 3. Average VHN values and Intensity of the [110] preferred orientation peak (VHN measured in the plane perpendicular to the rolling direction (transversal plane)).

A: annealed NA: No anneal

\begin{tabular}{|c|c|c|c|c|c|c|c|}
\hline & \multirow[t]{2}{*}{ original } & \multicolumn{2}{|c|}{ Roll 5\% } & \multicolumn{2}{|c|}{ Roll 10\% } & \multicolumn{2}{|c|}{ Roll 15\% } \\
\hline & & NA & A & NA & A & NA & A \\
\hline $\begin{array}{c}\overline{\mathrm{VHN}} \\
\left(\mathrm{kg} / \mathrm{mm}^{2}\right)\end{array}$ & 175 & 217 & 198 & 148 & 147 & 154 & 176 \\
\hline
\end{tabular}

\section{CONCLUSION}

Microstructure and micro-hardness investigation on SS-405 samples have been carried out to observe the occurrence of microstructural and hardness changes in the materials after being "cold rolled" with the true strains ranging from 5 percent, 10 percent and up to 15 percent respectively, at the designated temperature of $350{ }^{\circ} \mathrm{C}$; Concurrently followed by an investigation to observe the occurrence of microstructural and some mechanical properties changes in some of the same samples after annealing at $500{ }^{\circ} \mathrm{C}$ for 5 hours. It is concluded that both rolling and roll-annealing processes affect the mechanical properties of the samples. In the roll-anneal case a less significant change but with similar pattern as for the non-anneal case occurs. In the same vein it could be said that the average micro-hardness values of the roll-anneal samples are lower compared to the average micro-hardness values in roll-only samples The most significant variation occurs for non-annealed sample at $10 \%$ deformation, (parallel plane), and for non-annealed sample at $5 \%$ deformation (perpendicular plane) Therefore a higher degree of deformation as well as annealing do not always result in higher VHN hardness value. Another conclusion is that a higher degree of deformation could reduce the VHN values significantly. The [110]-peak intensity in both the just-roll and roll-anneal cases has increase tremendously. More significantly so in the non-anneal case. The preferred orientation vector here has shifted significantly and progressively toward the [110] direction. Influenced by the degree of deformation, and annealing seems to have less significant effect on preferred orientation. As a comparison, instrumented micro-indention tests revealed that Martens (Universal) Hardness values are more dependent on the resistance to dislocation motion than measured uniaxial pseudoelastic in a shape memory alloy. Based on comparison of hardness and the stress required to induce martensite, it is shown that the resistance to dislocation motion and the ease of the stress-induced martensite transformation cannot be simultaneously maximized, although an optimal combination should exist. Measuring indentation depth before and after heating more distinctly confirmed shape memory or pseudoelastic behavior 
[3]. Also microhardness measurements in a low carbon lamination steel after $6 \%$ of temper rolling confirms the equivalence between hardness values and the stored energy of cold work. A definite correlation between stored energy and Taylor factors could therefore be established, being more consistent than previous data reported in the literature [4].

\section{ACKNOWLEDGEMENTS}

The Authors would like to express their gratitude to Mr. Gunandjar S.U., former Head of Material Research and Development Center, Indonesian National Nuclear Energy Agency, for his suggesting this project and for the valuable support in creating a conducive environment so that this program could be carried out.

\section{REFERENCES}

1. ROY A. LINBERG, "Process and Materials Manufacture", Prentice Hall of India, Private Limited, New Delhi 110001, (1982).

2. E. A. AVALONE and TH. BAUMEISTER III, "Marks Standard Handbook for Mechanical Engineering", $10^{\text {th }}$ ed., McGraw-Hill Int. ed. (1997).

3. CARL P. FRICK耳ALICIA M. ORTEGA, JEFFREY TYBER, A.EL.M. MAKSOUND, HANS J. MAIER, YINONG LIU and KEN GALL, Materials Science and Engineering: A, 405, 34 (2005).

4. S.F. CASTRO] J. GALLEGO] F.J.G. LANDGRAF and H.-J. KESTENBACH, Materials Science and Engineering: A, 427, 301 (2006).

5. K. INOUE, M. SUGIMOTO, H. MAEDA, T. HORIKAWA, T. TSUJIKAMI, N. MINAKAWA, A. MORIAI and F. IKUTA, Residual Stress in Induction hardened S45C Round Bar, JAERI-Review, 2004-2005, 119 (2004).

6. Y. TOMOTA, M. UNO, T. SUZUKI, A. MORIAI, N. MINAKAWA and Y. MORII, Residual Grain Stress and Ultra-high Strength of a Heavily Drawn Ferrite Steel, JAERI-Review, 2004-2005, 125 (2004).

7. K. INOUE, T. HORIKAWA, H. NAKAMURA, N. MINAKAWA, Y. MORII, N. IKEDA and RUDIONO, Residual Strain Measurements of a Round Steel Bar with a Diameter of $40 \mathrm{~mm}(\mathrm{II})$, JAERI-Review 1998-1999, 54 (2000). 
8. "Typical Physical Properties of Stainless Steels ", Adv. Mater. Proc., December (2000);

9. www.OnlineMetals.com, Metal Technet, (2005).

10. "Ferritic Stainless Steels-Mechanical Properties", www.knightgroup.co.uk Technet (2005).

11. Determination of Strains and Flow Properties in Steels from Hardness / \begin{tabular}{ll|ll}
\hline Microhardness & Tests & (PDF) www.atc-ssm.com/PDF/MTA-14A.pdf
\end{tabular} http://web.cc.yamaguchi.ac.jp/ icmit01/programme.html (2005).

12. ASM Handbook, "Properties and Selection Iron, Steel, and High Performance Alloys", 1, 10 ${ }^{\text {th }}$ edition, (1990).

13. J. GOODHEW, Specimen Preparation In Materials Science, North Holland, American Elsevier, (1973).

14. WILliam F. SMITH, Structure and Properties of Engineering Materials, McGraw-Hill, 2nd edition, (1993).

15 A. PORTER and KENNETH E. EASTERLING, Phase Transformations in Metals and Alloys, Chapman and Hall, London, (1991).

16. G. S. BRADY, H.R. CLAUSER and J.A. VACCARI, "Materials Handbook", Fifteenth edition, Mc Graw Hill, New York (2000); http://metglas.com/downloads/lit(August 2005).

17. Handbook of Stainless Steel, (1994).

18. M.H. JACOBS, R.B. NEWBERY, I.TAYLOR and J.P. COAD, Heat Treatment, 84, 21. 


\begin{abstract}
ABSTRAK
EFEK PENGEROLAN DAN ANIL PADA MIKROSTRUKTUR DAN KEKERASAN BAHAN SS-405 PASARAN. Telah dilakukan percobaan pengerolan dingin untuk beberapa besaran regangan yang sebenarnya, yaitu $5 \%, 10 \%$ dan $15 \%$ pada baja SS-405 pasaran pada temperature $350{ }^{\circ} \mathrm{C}$; kemudian sampel dipotong-potong menjadi beberapa bagian dengan ukuran $10 \times 10 \times 5 \mathrm{~mm}^{3}$, dan pada sebagian potongan tersebut dilakukan penganilan pada $550{ }^{\circ} \mathrm{C}$ selama 24 jam. Setelah itu seluruh sample dibingkai dan dipoles sebelum kemudian dietsa untuk mengamati batas-batas butirnya. Pengamatan seluruh sample dilakukan dengan menggunakan mikroskop optik (MO), sedangkan difraksi sinar-x dilakukan untuk membantu identifikasi fasa-fasa yang ada maupun perubahan orientasi yang terjadi; pengujian kekerasan dilakukan dengan menggunakan alat uji kekerasan Vickers mikro. Hasil pengamatan struktur mikro yang didukung dengan difraksi sinar-X menunjukkan bahwa bentuk butir fasa pada sample yang telah di roll cenderung agak pipih memanjang, serta terjadi preferred orientation yang dominan ke arah bidang (110). Hasil uji kekerasan mikro menunjukkan bahwa telah terjadi peningkatan kekerasan pada sample-sampel yang di roll; tebal sample awal yang hanya $5 \mathrm{~mm}$, maka pada pengerolan 15 persen terjadi penurunan kekerasan dibandingkan dengan pengerolan 10 persen; hal ini terjadi karena pada sample yang telah diroll 15 persen, sebagian dislokasi telah keluar menembus permukaan sehingga pada sample terjadi penurunan tegangan dalam. Pada sample-sample roll yang dianil terjadi penurunan kekerasan, khususnya jika dibandingkan terhadap samplesampel yang hanya di roll. Hal ini dikarenakan adanya proses rekrsistalisasi pada anil yang mereduksi dislokasi secara berarti.
\end{abstract}

